\title{
Resepsi Mahasiswa Terhadap Nilai Moral Tokoh Utama dalam Novel “Ayat-Ayat Cinta 1" Karya Habiburrhman El Shirazy
}

\author{
Wulandari Nur Fajriyah ${ }^{1)}$, Yumna Rasyid ${ }^{2)}$, Nuruddin ${ }^{3)}$ \\ wulandarinf@ gmail.com ${ }^{1)}$, yumna.rasyid@unj.ac.id ${ }^{2)}$, nuruddin@unj.ac.id ${ }^{3)}$ \\ Program Studi Pendidikan Bahasa Indonesia \\ Universitas Negeri Jakarta, Indonesia
}

\begin{abstract}
Abstrak. Tujuan penelitian ini adalah untuk mendeskripsikan resepsi mahasiswa semester VI C Jurusan PBSI (Pendidikan Bahasa dan Sastra Indonesia) UIN Syarif Hidayatullah Jakarta yang sudah membaca novel "Ayat-ayat Cinta 1". Resepsi mahasiswa terhadap nilai moral tokoh utama dalam novel Ayat-ayat Cinta 1 karya Habiburrahman El Shirazy tersebut mencakup: (1) nilai moral agama; (2) nilai moral kepribadian; dan (3) nilai moral sosial. Data penelitian kulitatif ini diperoleh melalui angket dan wawancara. Prosedur pengumpulan data dilakukan dengan cara: menyebarkan angket, melakukan wawancara, mengumpulkan data, mengklasifikasi data, dan menganalisis data. Hasil penelitian menunjukkan bahwa nilai moral agama tokoh utama baik dengan persentase 9,3\%, begitupula dengan nilai moral kepribadian dengan persentase $9,0 \%$, dan nilai moral sosialnya dengan persentase $9,6 \%$. Nilai moral tokoh utama dapat menjadi teladan dan pelajaran bagi mahasiswa sehingga dapat membentuk karakter yang kuat dalam nilai moral beragama, nilai moral kepribadian, dan nilai moral sosial.
\end{abstract}

Kata Kunci: resepsi sastra, novel, pembaca, nilai moral

\section{Pendahuluan}

Penanaman nilai moral sangat dibutuhkan bagi pendidikan karena nilai moral membentuk kepribadian siswa dalam bertindak di lingkungan sosial. Seperti yang dikatakan oleh Zuriah yang mendefiniskan bahwa nilai terdapat pembakuan tentang hal baik dan hal buruk serta pengaturan prilaku (2008) dan moral diartikan sebagai nilai-nilai yang menjadi pegangan bagi seseorang dalam mengatur tingkah lakunya (Bertens, 2013). Nilai moral dikategorikan menjadi nilai moral agama, nilai moral kepribadian, dan nilai moral sosial (Soeparwoto, 2004) begitupula dengan Suseno yang mengkategorikan nilai moral dengan istilah etika wahyu, etika peraturan, dan etika situasi. Dalam penilitian ini menggunakan istilah dari Soeparwoto yang didukung oleh artikel penelitian yang dilakukan oleh Nur Kholis, dkk. Dengan judul "Nilai-nilai Moral dalam Novel Negeri Menara karya A.Fuadi" dengan mengkategorikan: nilai moral ketuhanan, nilai moral individual, dan nilai moral sosial (Jurnal Universitas Negeri Malang Vol. 1 No. 1, 2012). Selanjutnya, Nashruddin (2015) menjelaskan bahwa nilai moral dalam agama Islam dikenal dengan istilah akhlak. Definisi akhlak agama Islam tidak akan sama dengan definisi etika dan moral sebab akhlak merupakan prilaku mahmudah dan prilaku mazmumah, baik berprilaku kepada Allah, manusia, dan lingkungannya yang sudah terabadikan dalam Alquran dan Al-Sunnah. Pengertian tersebut menunjukkan bahwa nilai moral dalam Islam juga dikategorikan menjadi

Wulandari Nur Fajriyah, Yumna Rasyid, Nuruddin | Resepsi Mahasiswa Terhadap Nilai Moral Tokoh Utama 
prilaku baik kepada Allah, berprilaku baik kepada diri sendiri dan sesama manusia, dan berprilaku baik kepada lingkungan sosial yang sesuai dengan Alquran dan Al-Sunnah.

Dalam pembelajaran sastra, tingkah laku tokoh utama dalam novel dapat dijadikan pembelajaran nilai moral. Seperti yang disampaikan oleh Wellek dan Werren (2014) novel merupakan gambaran kehidupan dan prilaku nyata. Melalui prilaku tokoh dapat diketahui nilai moral agama, nilai moral kepribadian, dan nilai moral sosial yang dapat dinilai oleh pembaca. Segers (2000) membagi beberapa kategori pembaca, yaitu: pembaca ideal, pembaca implisit, dan pembaca ril. Reaksi yang ditimbulkan oleh pembaca dapat berupa positif dan negatif.

Penelitian yang relevan dengan penelitian ini telah dilakukan oleh Puji Santoso 2017 dalam Jurnal Aksara Vol. 29 No. 1 berjudul "Resepsi Sastra Kisah Gandari dalam Puisi Indonesia Modern”. Perbedaannya terletak pada metode resepsi sastra yang digunakan, dalam penelitian Puji menggunakan resepsi sastra pada setiap zaman atau diakronis mengenai pemaknaan terhadap transformasi kisah Gandaria sedangan penelitian ini menggunakan resepsi sastra pada satu zaman atau sinkronis dan secara langsung ke lapangan untuk mengetahui tanggapan mahasiswa terhadap nilai moral tokoh utama.

Selain itu, ada juga penelitian yang dilakukan oleh Niken Savitri, Univrsitas Muhammadiyah Purworwjo, 2015 dengan judul "Analisis Resepsi Sastra Cerita Sambung Ngonceki Impen karya Sri Sugiyanto”. Persamaan dengan penelitian ini adalah sama-sama melakukan penelitian terkait dengan tanggapan beberapa orang. Perbedaannya terletak pada fokus penelitian. Penelitian ini berfokus pada tanggapan mahasiswa terhadap nilai moral tokoh utama dalam novel "Ayat-ayar Cinta 1" karya Habiburrahman El Shirazy terkait dengan nilai moral agama, nilai moral kepribadian, dan nilai moral sosial. Sedangkan penelitian yang dilakukan Niken Savitri berfokus pada tanggapan mahasiswa terhadap struktur cerita bersambung.

\section{Metode}

Tujuan penelitian ini adalah untuk mengetahui dan memperoleh pemahaman yang mendalan berhubungan dengan penerimaan mahasiswa dalam bentuk tanggapan, penerimaan, yang dikategorikan sebagai positif berarti setuju dan negatif berarti tidak setuju mengenai nilai moral tokoh utama dalam novel "Ayat-ayat Cinta 1" karya Habiburrahman El Shirazy.

Sumber data dalam penelitian ini adalah mahasiswa semester VI C jurusan PBSI (Pendidikan Bahasa dan Sastra Indonesia) UIN Syarif Hidayatullah Jakarta 10 mahasiswa. Dalam memperoleh data, peneliti dibantu menggunakan kuesioner dalam bentuk pernyataan dan wawancara. Data penelitian ini adalah tanggapan mahasiswa terkait dengan fokus penelitian nilai moral tokoh utama yang mencakup: nilai moral agama, nilai moral kepribadian, dan nilai moral sosial tokoh utama dalam novel "Ayat-ayat Cinta 1" karya Habiburrahman El Shirazy.

Langkah-langkah yang dilakukan untuk menganalisis data dalam penelitian adalah sebagai berikut: 1) membaca dan mendata hasil tanggapan mahasiswa terhadap kuesioner yang dibagikan dan wawancara; 2) menulis dan mengklasifikasikan tanggapan mahasiswa

Wulandari Nur Fajriyah, Yumna Rasyid, Nuruddin | Resepsi Mahasiswa Terhadap Nilai Moral Tokoh Utama 
dalam tabel analisis untuk mendapatkan pemahaman tentang seluruh tanggapan yang diperoleh dari kuesioner; 3) hasil kuesioner diklasifikasikan menurut kriteria analisis ke dalam tabel analisis untuk mengetahui respons yang berkaitan dengan nilai moral agama, nilai moral kepribadian, dan nilai moral sosial; 4) menghitung jumlah dan presentase pada masing-masing fokus penelitian; 5) melalukan interpretasi data dan mendeskripsikan hasil tanggapan mahasiswa yang telah diklasifikasikan sehingga diperoleh pemahaman utuh tentang tanggapan pembaca terhadap nilai moral tokoh utama; 6) membuat kesimpulan.

\section{Hasil dan Pembahasan}

Melalui kajian resepsi dan pembaca akan diketahui seberapa jauh penelitian ini akan berguna untuk tujuan mengetahui secara mendalam tanggapan pembaca terhadap nilai moral tokoh utama dalam novel "Ayat-ayat Cinta 1" karya Habiburrahman El Shirazy. Sastra menggunakan metode sugestif tentu akan menghidupkan kembali keinginan pembaca. Oleh karena itu, sastra secara langsung dan tidak langsung akan mengadopsi tanggapan penting pembaca. Sastra memiliki estetika kuat dan secara otomatis juga memiliki kekuatan terhadap para pembaca.

Tabel 1. Tanggapan Mahasiswa terhadap Nilai Moral Agama Tokoh Utama

\begin{tabular}{|c|c|c|c|c|c|c|c|c|c|c|c|c|}
\hline \multirow[t]{2}{*}{ No } & \multirow[t]{2}{*}{ Pernyataan Kuesioner } & \multicolumn{10}{|c|}{ Pendapat Mahasiswa } & \multirow[t]{2}{*}{$\begin{array}{l}\text { Persent } \\
\text { ase }\end{array}$} \\
\hline & & 1 & 2 & 3 & 4 & 5 & 6 & 7 & 8 & 9 & 10 & \\
\hline 1 & Yakin akan keberadaan Allah & I & I & I & I & $\mathrm{I}$ & I & I & I & $\mathrm{I}$ & I & $100 \%$ \\
\hline 2 & $\begin{array}{l}\text { Menaati semua perintah dan menjauhi segala } \\
\text { larangan Allah }\end{array}$ & I & I & II & I & II & I & I & I & I & I & $90 \%$ \\
\hline & Sabar dan tabah dalam menjalankan perintah & & & & & & & & & & & $100 \%$ \\
\hline 3 & Allah & I & I & I & I & $\mathrm{I}$ & I & I & I & I & I & \\
\hline 4 & Sabar dan tabah dalam menjauhkan larangan & I & I & J & I & I & I & I & & & & $95 \%$ \\
\hline $\begin{array}{l}4 \\
5\end{array}$ & $\begin{array}{l}\text { Allan } \\
\text { Rendah hati ke }\end{array}$ & $\begin{array}{l}1 \\
\mathrm{I}\end{array}$ & $\begin{array}{l}1 \\
\mathrm{I}\end{array}$ & $\begin{array}{l}1 \\
\mathrm{I}\end{array}$ & $\begin{array}{l}1 \\
\mathrm{I}\end{array}$ & I & $\begin{array}{l}1 \\
I\end{array}$ & $\begin{array}{l}1 \\
\mathrm{I}\end{array}$ & $\begin{array}{l}1 \\
I\end{array}$ & $\begin{array}{l}11 \\
\text { I }\end{array}$ & $\begin{array}{l}1 \\
\mathrm{I}\end{array}$ & $100 \%$ \\
\hline 6 & Berharap kepada Allah & I & $\mathrm{I}$ & $\mathrm{I}$ & I & $\mathrm{I}$ & I & I & I & I & I & $100 \%$ \\
\hline 7 & Berserah diri kepada Allah & I & $\mathrm{I}$ & II & $\mathrm{I}$ & $\mathrm{I}$ & $\mathrm{I}$ & I & I & I & I & $95 \%$ \\
\hline 8 & Bersyukur atas segala nikmat kepada Allah & $\mathrm{I}$ & I & II & II & I & I & I & $\mathrm{I}$ & I & I & $90 \%$ \\
\hline 9 & Teguh pendirian dalam menegakkan tauhid & $\mathrm{I}$ & $\mathrm{I}$ & II & I & $\mathrm{I}$ & I & I & I & I & I & $95 \%$ \\
\hline 10 & Semua yang dimiliki adalah titupan Allah & $\mathrm{I}$ & $\mathrm{I}$ & $\mathrm{I}$ & $\mathrm{I}$ & $\mathrm{I}$ & $\mathrm{I}$ & $\mathrm{I}$ & $\mathrm{I}$ & $\mathrm{I}$ & I & $100 \%$ \\
\hline 11 & Berdoa hanya kepada Allah & $\mathrm{I}$ & $\mathrm{I}$ & $\mathrm{I}$ & I & $\mathrm{I}$ & $\mathrm{I}$ & $\mathrm{I}$ & I & I & $\mathrm{I}$ & $100 \%$ \\
\hline 12 & $\begin{array}{l}\text { Mengingat Allah dalam berbagai keadaan } \\
\text { Bersikap malu karena melanggar perintah }\end{array}$ & I & $\mathrm{I}$ & $\mathrm{I}$ & $\mathrm{I}$ & II & $\mathrm{I}$ & $\mathrm{I}$ & I & $\mathrm{I}$ & I & $\begin{array}{l}95 \% \\
100 \%\end{array}$ \\
\hline 13 & Allah & $\mathrm{I}$ & $\mathrm{I}$ & $\mathrm{I}$ & $\mathrm{I}$ & $\mathrm{I}$ & $\mathrm{I}$ & $\mathrm{I}$ & I & $\mathrm{I}$ & I & \\
\hline
\end{tabular}

Keterangan: Angka 1-10 menunjukkan responden

I menyatakan pendapat setuju dan II menyatakan pendapat tidak setuju

Berdasarkan data tersebut dapat diketahui seluruh mahasiswa setuju dengan persentase $100 \%$ bahwa tokoh utama yakin akan keberadaan Allah karena tokoh utama rajin melaksanakan ibadah shalat, puasa, selalu menyebut kalimat Allah, rajin membaca Alquran, dan taat kepada perintah Allah.

Mahasiswa juga menyatakan setuju dengan persentase $90 \%$ bahwa tokoh utama menaati semua perintah Allah dan menjauhi segala larangan-Nya karena tokoh utama tidak

Wulandari Nur Fajriyah, Yumna Rasyid, Nuruddin | Resepsi Mahasiswa Terhadap Nilai Moral Tokoh Utama 
pernah meninggalkan kewajibannya sebagai muslim, seperti beribadah shalat wajib dan shalat sunnah. Dari hasil wawancara mahasiswa mengungkapkan bahwa tokoh utama dapat menjauhkan larangan yang ada dalam Alquran, seperti tidak berjudi, tidak melakukan zina, tidak minum alkohol, dan tidak meninggalkan shalat lima waktu.

Berdasarkan data tersebut dapat diketahui bahwa tokoh utama sabar dan tabah dalam menjalankan perintah Allah dengan perseantse 100\%, sabar dan tabah dalam menjauhi larangan Allah dengan persentase 95\%. Dari hasil wawancara mahasiswa karena tokoh utama menjalankan perintah Allah, seperti shalat, puasa, berdoa, membaca Alquran tanpa adanya keterpaksaan dari pihak manapun. Mahasiswa menyatakan bahwa tokoh utama sabar dan tabah dalam menghadapi tuduhan fitnah sampai dipenjara, tidak bersikap berontak dan marah-marah tetap menjalani dengan sabar, tabah, tidak mudah putus asa, dan terus berusaha membuktikan bahwa dirinya tidak bersalah. Selain itu, tokoh utama sabar dan tabah dalam menjauhkan larangan Allah karena menjauhi sifat bohong, iri, dengki, tidak bersyukur, dan tidak mengeluh.

Berdasarkan data tersebut, seluruh mahasiswa setuju dengan persentase $100 \%$ bahwa tokoh utama bersikap rendah hati karena tokoh utama berdoa, memohon, dan meminta perlindungan hanya kepada Allah dan tidak sombong dengan apa yang dimilikinya kepada orang lain. Tokoh utama menyadari bahwa tidak ada yang patut disombongkankan dalam dirinya kepada Allah dan orang lain karena Allah yang menciptakan dan memberikan kelebihan serta kekurangan. Mahasiswa juga berpendapat tokoh utama tidak sombong karena mau melaksanakan dan menerima kebenaran dengan bersikap lembut tanpa membusungkan dada.

Berdasarkan data tersebut dapat diketahui seluruh mahasiswa setuju dengan persentase $100 \%$ bahwa tokoh utama berharap hanya kepada Allah karena tokoh utama mencurahkan segala harapannya, seperti berharap untuk keselamatan orang tua, berharap segera dipertemukan jodoh, berharap mendapatkan nilai bagus, berharap dapat segera bebas dari tuduhan fitnah, dan berharap bebas dari penjara. Mahasiswa juga berpendapat bahwa harapan tokoh utama tersebut diiringi dengan usaha tokoh utama dengan mendoakan kedua orang tua dan selalu memberikan kabar kepada kedua orang tuanya, menerima proses taaruf dari gurunya untuk mendapatkan jodoh, belajar sungguh-sugguh untuk mendapatkan nilai bagus, dan berusaha mencari saksi kunci agar dirinya dapat bebas dari tuduhan fitnah. Setelah berusaha, tokoh utama berdoa dengan harapan-harapan tersebut dan meyerahkan segala harapannya kepada Allah. Dengan berharap hanya kepada Allah maka tidak akan ada harapan yang sia-sia dan jika berharap kepada selain Allah akan mendatangkan kekecewaan.

Berdasarkan tanggapan mahasiswa dengan persentase 95\% menyatakan setuju bahwa tokoh utama bersikap tawakal karena tokoh utama bersikap sabar dan beriman kepada Allah menjadikan dirinya menyerahkan segala urusan yang telah dilakukan hanya kepada Allah. Tokoh utama belajar rajin dan bersungguh-sungguh dalam menghadapi ujian tetapi menyerahkan segala hasilnya kepada Allah. Tokoh utama berusaha mencari saksi untuk mendapatkan pembelaan bahwa diinya tidak bersalah, tokoh utama berusaha menyakinkan diri denga shalat istikharah sebelum melakukan ta'aruf. Segala usaha yang dilakukan tokoh utama tersebut diserahkan sepenuhnya kepada takdir Allah.

Wulandari Nur Fajriyah, Yumna Rasyid, Nuruddin | Resepsi Mahasiswa Terhadap Nilai Moral Tokoh Utama 
Dari respons yang diberikan mahasiswa dengan persentase $90 \%$ dapat diketahui bahwa mahasiswa setuju tokoh utama bersyukur kepada Allah karena tokoh utama mengucap rasa syukur alhamdulillah dan melakukan sujud syukur saat bebas dari tuduhan fitnah. Tokoh utama menunjukkan rasa syukur dengan berbagi makanan kepada temanteman satu flatnya ketika proposal tesisnya diterima. Rasa syukur atas segala nikmat yang telah diberikan Allah dengan beribadah dan berdoa hanya kepada Allah.

Berdasarkan data tersebut dapat diketahui tanggapan mahasiswa setuju dengan persentase $95 \%$ bahwa tokoh utama teguh dalam menegakkan tauhid karena tokoh utama tidak menyembah selain Allah, taat beribadah, berharap hanya kepada Allah, menyerahkan segala urusan kepada Allah, mengamalkan isi Alquran dengan mengajak sesama muslim untuk memulikan tamu. Mahasiswa juga berpendapat bahwa tokoh utama melakukan segala sesuatu dengan konsisten tidak mudah galau dan melakukan segala sesuatu semata-mata hanya karena Allah.

Berdasarkan data tersebut seluruh mahasiswa setuju dengan pesentase 100\%, dapat menyatakan bahwa tokoh utama memiliki kedekatan hubungan dengan Allah karena tokoh utama menyadari semua yang dimilikinya di dunia fana ini hanyalah titipan dari Allah dan akan kembali kepada Allah. Tokoh utama hidup sederhana, tidak berlebih-lebihan dalam makanan, berpakaian, dan menggunakan uang. Selain itu, tokoh utama menyadari bahwa kehidupan di dunia bersifat sementara, yang kekal abadi di akhirat nanti. Kemudian, seluruh mahasiswa setuju dengan persentase $100 \%$ bahwa kedekatan hubungan tokoh utama dengan Allah melalui berdoa. Dan berdasarkan data tanggapan mahasiswa dengan persentase 95\% menyatakan bahwa tokoh utama memiliki kedekatan dengan Allah melalui megingat nama Allah dengan berdzikir. Dengan berdoa, berdzikir, dan beribadah berarti tokoh utama menghadap secara langsung kepada Allah. Berkomunikasi dalam setiap bacaan shalat dan doa yang dipanjatkan kepada Allah. Doa yang dipanjatkan tokoh utama adalah mengharapkan kesehatan orang tua, bertemu jodoh, dan segera menyelesaikan studi S-2 nya.

Berdasarkan data tersebut seluruh mahasiswa setuju dengan persentase $100 \%$ bahwa tokoh utama bersikap malu sebab melanggar perintah Allah karena tokoh utama memohon ampunan Allah ketika menyadari bahwa dirinya menangisi masalah duniawi yaitu menangisi surat dikeluarkannya dari Universitas Al Azhar, Kairo. Tokoh utama juga merasa malu kepada Allah ketika lupa melaksanakan shalat zuhur karena tertidur. Mahasiswa juga berpendapat bahwa tokoh utama ketika melakukan kesalahan baik disengaja maupun tidak disengaja juga merasa malu dan langsung memohon ampunan kepada Allah.

Tabel 2. Tanggapan Mahasiswa terhadap Nilai Moral Kepribadian Tokoh Utama

\begin{tabular}{|c|c|c|c|c|c|c|c|c|c|c|c|c|}
\hline \multirow[t]{2}{*}{ No } & \multirow{2}{*}{ Pernyataan Kuesioner } & \multicolumn{10}{|c|}{ Pendapat Mahasiswa } & \multirow[t]{2}{*}{$\begin{array}{l}\text { Persenta } \\
\text { se }\end{array}$} \\
\hline & & 1 & 2 & 3 & 4 & 5 & 6 & 7 & 8 & 9 & 10 & \\
\hline 14 & $\begin{array}{l}\text { Menjaga kebersihan, kesehatan, dan } \\
\text { kesucian diri }\end{array}$ & I & I & I & II & I & I & I & I & I & I & $95 \%$ \\
\hline 15 & Bersikap mandiri & $\mathrm{I}$ & I & II & I & I & I & I & I & I & I & $95 \%$ \\
\hline 16 & Menghormati sesama manusia & I & $\mathrm{I}$ & I & I & I & I & I & I & I & I & $100 \%$ \\
\hline 17 & $\begin{array}{l}\text { Memperhatikan lawan bicara saat } \\
\text { berkomunikasi }\end{array}$ & I & I & I & II & II & I & I & I & I & I & $90 \%$ \\
\hline
\end{tabular}


18 Berani berpihak pada yang lemah

19 Berani mempertahankan sikap yang diyakini

20 Bersedia mengambil risiko

21 Memiliki tanggung jawab realistik Menyelesaikan tugas yang

22 membebani

23 Bersikap tanpa pamrih

32 Mendengarkan semua pihak sebelum memberikan penilaian

Keterangan: Angka 1-10 menunjukkan responden

I menyatakan pendapat setuju dan II menyatakan pendapat tidak setuju

Berdasarkan data tersebut seluruh mahasiswa setuju dengan persentase $95 \%$ bahwa tokoh utama dapat menjaga kebersihan, kesehatan, dan kesucian diri sendiri karena tokoh utama rajin mandi untuk membersihkan badannya, untuk menjaga kesehatan tempat tinggalnya, tokoh utama melakukan bersih-bersih pada kamar dan tempat tinggalnya. Dalam menjaga kesucian diriya tokoh utama selalu menjaga wudhunya sepanjang waktu, apabila dirinya batal maka segera mengambil air wudhu. Mahasiswa juga memberikan pendapat bahwa tokoh utama menjaga kesehatan karena makan dan minum dengan teratur dan dapat menjaga kebersihan pakaiannya. Tokoh utama menggunakan pakaian bersih dan tidak pernah digambarkan kotor karena tokoh utama menyadari bahwa kebersihan adalah sebagian dari imam.

Berdasarkan data tersebut seluruh mahasiswa setuju dengan persentase $95 \%$ bahwa tokoh utama mandiri karena dapat membiayai pendidikan S-1 sampai S-2 di Universitas Al Azhar, Kairo dan dapat memenuhi kebutuhan hidup di negara Mesir tanpa bergantung dengan siapapun. Tokoh utama menjadi penerjemah kitab bahasa Arab ke dalam bahasa Indonesia untuk membiaya pendidikan dan hidup di Mesir. Mahasiswa juga berpendapat bahwa tokoh utama dapat mengatur segala keperluannya sendiri apa yang dibutuhkan dan yang tidak dibutuhkan sehingga dapat mengatur pengeluaran dengan bijak. Tokoh utama dapat hidup sendiri di Mesir yang jauh dari Indonesia tanpa bertemu keluarganya bertahuntahun.

Dari respons yang diberikan mahasiswa, dapat diketahui seluruh mahasiswa setuju dengan persentase $100 \%$ bahwa tokoh utama menghormati orang-orang yang berada di sekitanya karena tokoh utama ramah, suka menyapa orang yang ditemuinya baik yang 
dikenal maupun tidak dikenal, seperti bertemu dengan Ali di Metro tokoh utama belum mengenal namun menyapa dengan ramah dan terjadilah percakapan dan saling mengenal. Mahasiswa juga berpendapat bahwa tokoh utama menghormati orang lain karena setiap bertemu dengan teman, guru, dan orang-orang yang berada di sekitarnya mengucapkan salam assalamualaikum warahmatullahiwabarakatuh, menyapa dengan ramah, dan tersenyum.

Berdasarkan data tersebut seluruh mahasiswa setuju dengan persentase $90 \%$ bahwa tokoh utama memperhatikan lawan bicara saat berkomunikasi karena tokoh utama berhatihati sebelum berbicara, mempertimbangkan ucapannya sebelum berbicara dengan melihat latar belakang lawan bicara. Saat menghadapi orang Mesir yang sedang marah tokoh utama mula-mula meredam amarahnya terlebih dahulu dengan mengajak bershalawat setelah itu tokoh utama mulai berbicara. Mahasiswa juga berpendapat bahwa tokoh utama memperhatikan Noura ketika berkomunikasi, pertama-tama ketika menolong Noura, tokoh utama tidak langsung bertanya alasan kenapa Noura dipuluk oleh Ayah dan saudarnya sendiri tapi menenangkan Noura dengan membawanya ke tempat yang aman dengan meminta bantuan Nurul agar dapat membantu Noura dengan memberikan izin tinggal sementara di asrama putri Indonesia sampai menemukan solusi dari permasalahan Noura. Tokoh utama juga memperhatikan lawan bicaranya Alicia yang bersal dari Amerika, tokoh utama menggunakan bahasa Inggris untuk berkomunikasi dengan Alicia. Begitupula dengan Aisyah, tokoh utama menggunakan bahasa Jerman saat berkomunikasi dengan Aisyah.

Berdasarkan data tersebut, tanggapan mahasiswa menyatakan setuju bahwa tokoh utama memiliki keberanian hidup dengan berani berpihak pada yang lemah dengan persentase $85 \%$ karena berani menolong dan membela tetangganya, Noura yang mendapatkan penyiksaan setiap hari dari Ayah dan saudaranya. Noura tidak melawan dan mendapatkan bantuan dari siapapun selain dari tokoh utama. Tokoh utama juga membela Aisyah, Alicia dan teman-temannya yang lemah karena terpojokkan dengan makian orang Mesir di dalam metro. Selanjutnya, pendapat mahasiswa menyatakan bahwa dengan tindakan berani membela orang-orang yang lemah tersebut berarti tokoh utama berani mengambil risiko. Tokoh utama juga memiliki keberanian hidup dengan mau menerima risiko dari perbuatan yang telah dilakukannya. Berdasarkan data tersebut seluruh mahasiswa setuju dengan persentase $100 \%$ bahwa tokoh utama siap menerima risiko katahuan oleh Ayah Noura dan diperlakukan kasar ketika menolong Noura. Begitupula ketika membela Aiyah, Alicia dan teman-temannya dalam metro, tokoh utama berani mengambil risiko menghadapi amarah orang-orang Mesir dalam metro tersebut. Kemudian, tokoh utama juga memiliki keberanian hidup dengan mempertahankan sikap yang diyakini. Berdasarkan data tanggapan seluruh mahasiswa setuju dengan persentase $100 \%$ menyatakan bahwa tokoh utama dapat mempertahankan sikap tegas dan akhlak terpujinya dengan tidak berbuat curang untuk bebas ketika dipenjara. Tokoh utama juga mempertahankan sikapnya yang taat hanya kepada Allah dan tidak malas melaksanakan ibadah. Mahasiswa juga berpendapat bahwa tokoh utama mampu mempertahankan sikap untuk tetap menjauhi larangan Allah untuk tidak bersentuhan dengan wanita yang bukan mahramnya. Tokoh utama juga 
mempertahankan akhlak terpujinya, seperti sopan, ramah, dan konsisten dengan tugasnya walaupun diajak teman-temannya untuk keluar makan malam.

Berdasarkan data tersebut seluruh mahasiswa setuju dengan persentase $100 \%$ bahwa tokoh utama bersikap tanggung jawab realistik dengan segala aktifitas yang diambil dan dijalani. Tokoh utama bertanggungjawab belajar sungguh-sungguh, rajin kuliah, dan rajin mengaji. Mahasiswa juga berpendapat bahwa tokoh utama bertanggungjawab realistik sebagai suami yang memberikan nafkah lahir dan batin kepada istrinya.

Dari respons yang diberikan mahasiswa, dapat diketahui seluruh mahasiswa setuju dengan persentase $100 \%$ menyatakan bahwa tokoh utama menyelesaikan pekerjaan sebagai penerjemah, tanggung jawab menyelesaikan kuliah, dan tanggung jawab terhadap hukum yang berlaku di Mesir dengan menjalankan tuduhan fitnah dalam penjara mulai dari penahanan sampai putusan hakim. Mahasiswa juga berpendapat bahwa tokoh utama bertanggungjawab menyelesaikan tugasnya tanpa adanya keterpaksaan dari pihak manapun dan tanpa mengharapkan apapun dari orang lain.

Berdasarkan data tersebut seluruh mahasiswa setuju dengan persentase $100 \%$ bahwa tokoh utama bersikap tanpa pamrih karena tokoh utama ikhlas menolong Maria membelikan titipan keperluan kuliahnya tanpa mengharapkan imbalan dalam bentuk apapun. Tokoh utama juga tulus menolong Noura saat tetangga yang lain tidak ada yang peduli menolognya, justru mengusahakan izin tinggal di asrama putri Indonesia dan memberikan uang kepada Noura untuk memenuhi kebutuhan sementara Noura. Tokoh utama juga tidak mengharapkan imbalan atau pujian ketika menolong Aisyah, Alicia dan teman-temannya dalam metro.

Berdasarkan data tersebut seluruh mahasiswa setuju dengan persentase $100 \%$ bahwa tokoh utama melaksanakan tugas sebaik mungkin karena tokoh utama dapat menyelesaikan pekerjaan menerjemahkan dengan maksimal tanpa mengecewakan siapapun, tokoh utama juga mengerjakan tugas kuliahnya dengan sebaik mungkin karena mendapatkan hasil yang baik dan memuaskan. Mahasiswa juga berpendapat bahwa tokoh utama orang yang berdedikasi tinggi dalam mengatur waktu sehingga tokoh utama dapat mengerjakan tugas sebaik mungkin.

Dari respons yang diberikan mahasiswa, mahasiswa setuju dengan persentase $90 \%$ menyatakan bahwa tokoh utama bersikap tanggung jawab di mana saja dan seluruh mahasiswa dengan persentase $100 \%$ menyatakan bahwa tokoh utama bertanggungjawab atas tindakan yang telah dilakukan. Berdasarkan hasil wawancara mahasiswa mengemukakan alasan bahwa tokoh utama dapat bertanggungjawab di mana saja dan atas tindakan yang telah dilakukan karena menolong Noura ketika malam hari dan tetangga tidak ada yang peduli dan mau menolongnya. Tokoh utama menolong Noura sampai permasalahannya tuntas. Begitupula ketika menolong Aiysah, Alicia, dan teman-temannya saat dalam metro yang sedang ditumpanginya, dan tokoh utama sadar untuk bertanggungjawab belajar di mana saja, kapan saja tanpa mengenal batas ruang dan waktu. Tokoh utama dinilai orang yang bertanggungjawab karena berani mengambil risiko atas tindakan yang telah dilakukan, tokoh utama bertanggungjawab melaksanakan kewajibannya sebagai mahasiswa dengan belajar bersungguh-sungguh, tokoh utama berkomitmen untuk dapat segera menyelesaikan studinya.

Wulandari Nur Fajriyah, Yumna Rasyid, Nuruddin | Resepsi Mahasiswa Terhadap Nilai Moral Tokoh Utama 
Mahasiswa juga berpendapat bahwa tokoh utama bertanggungjawab karena tidak menyesal dan mengeluh dengan segala yang sudah terjadi.

Berdasarkan data tersebut mahasiswa setuju dengan persentase 95\% bahwa tokoh utama bersikap teguh pendirian kerana dapat konsisten mengikuti peraturan yang berlaku di Mesir dengan mengikuti seluruh prosedur hukum di Mesir mulai dari penangkapan, penyidikan, persidangan, samapai dengan putusan hakim padahal tokoh utama tidak bersalah. Mahasiswa juga berpendapat bahwa tokoh utama tidak pernah melakukan tindakan yang melanggar aturan yang berlaku di Mesir sehingga dia tidak pernah bermasalah dengan siapapun di Mesir. Kemudian, tokoh utama juga hidup dengan aman dan tenang tanpa adanya gangguan dari manapun karena taat dan mengikuti peraturan yang berlaku.

Selanjutnya, berdasarkan data tersebut seluruh mahasiswa setuju dengan persentase $100 \%$ bahwa tokoh utama tidak menyakiti orang lain dengan tidak menyakiti dan tidak memaki karena tokoh utama dapat menjaga perasaan orang lain dengan selalu mempertimbangkan tindakan dan ucapan yang akan disampaikan. Tokoh utama juga dinilai tidak pernah memiliki musuh dan tidak pernah berselisih dengan orang lain karena dia bisa menjaga sikap dan ucapannya yang tidak menyakiti dan memaki orang lain. Perkataan lembut tokoh utama dapat menyenangkan hati orang lain, begitu juga dengan sikap yang ramah tidak sombong serta dapat menghargai membuat orang lain merasa dihargai dan senang dengan pribadi tokoh utama. Sikap tersebut menjauhkan tokoh utama dari sikap memaki dan menyakiti orang lain. Mahasiswa juga berpendapat bahwa tokoh utama tidak pernah melakukan tindakan memaki dan menyakiti orang lain dengan demikian tokoh utama juga tidak pernah dimaki dan disakiti oleh orang lain.

Kemudian, berdasarkan data tersebut seluruh mahasiswa setuju dengan persentase $95 \%$ bahwa tokoh utama tidak merasa takut dan gentar kepada orang lain karena tokoh utama hanya merasa takut kepada Allah. Tokoh utama takut jikalau tidak taat kepada Allah, tidak melaksanakan ibadah, dan melanggar aturan Allah. Mahasiswa juga berpendapat bahwa tokoh utama berani menerima risiko dari tindakan yang telah dilakukan, tokoh utama tidak lari dari masalah tuduhan fitnah namun menghadapinya dan menyadari risiko dari berbuat baik, menolong orang lain, dan tokoh utama tidak merasa takut karena melakukan tindakan yang sesuai dengan aturan yang berlaku di masyarakat dan sesuai dengan Alquran.

Berdasarkan data tersebut mahasiswa setuju dengan persentase $90 \%$ bahwa tokoh utama tokoh utama mau berbagi karena berbagi makanan, minuman, dan lain sebagainya dengan teman-teman satu flatnya. Tokoh utama mau menolong orang-orang yang berada di sekitarnya. Mahasiswa juga berpendapat tokoh utama mau berbagi dan bergiliran dengan kedua istrinya. Tokoh utama dinilai dapat berbuat adil kepada kedua istrinya kerena memberikan kasih sayang yang sama kepada dua istrinya dengan tidak membeda-bedakan dan dapat menjadi imam untuk kedua istrinya sehingga istrinya tidak pernah saling bertengkar dan berselisih.

Berdasarkan tanggapan mahasiswa dengan persentase $90 \%$ menyatakan bahwa tokoh utama mau mendengarkan pendapat orang yang berada disekitarnya karena tokoh utama mendengarkan masukan dari istri dan teman-temannya saat menghadapi masalah di penjara, tokoh utama dapat mempertimbangkan pendapat dan masukkan tersebut dengan objektif

Wulandari Nur Fajriyah, Yumna Rasyid, Nuruddin | Resepsi Mahasiswa Terhadap Nilai Moral Tokoh Utama 
sehingga saat menghadapi masalah yang ada di penjara tokoh utama dapat menyelesaikannya dengan tenang. Mahasiswa juga berpendapat bahwa tokoh utama meminta pendapat teman-temannya sebelum memberikan kado untuk Ibu Maria dan adik Maria yang berulang tahun. Begitu pula sebelum menghadiri acara ulang tahun tersebut tokoh utama meminta pendapat dan kesepakatan dari teman-temannya.

Tabel 3. Tanggapan Mahasiswa terhadap Nilai Moral Sosial Tokoh Utama

\begin{tabular}{|c|c|c|c|c|c|c|c|c|c|c|c|c|}
\hline \multirow[t]{2}{*}{ No } & \multirow[t]{2}{*}{ Pernyataan Kuesioner } & \multicolumn{10}{|c|}{ Pendapat Mahasiswa } & \multirow[t]{2}{*}{$\begin{array}{l}\text { Persenta } \\
\text { se }\end{array}$} \\
\hline & & 1 & 2 & 3 & 4 & 5 & 6 & 7 & 8 & 9 & 10 & \\
\hline 33 & Tolong Menolong antar tetangga & I & I & I & I & 1 & I & I & I & I & I & $100 \%$ \\
\hline 34 & $\begin{array}{l}\text { Membantu orang yang sedang } \\
\text { kesusahan }\end{array}$ & I & I & I & I & 1 & I & I & I & I & I & $100 \%$ \\
\hline 35 & $\begin{array}{l}\text { Mengambil keputusan berdasarkan } \\
\text { kepentingan bersama }\end{array}$ & I & I & II & I & 1 & I & I & I & I & $\mathrm{I}$ & $95 \%$ \\
\hline 36 & $\begin{array}{l}\text { Memberikan kesempatan orang lain } \\
\text { untuk berpendapat }\end{array}$ & $\mathrm{I}$ & I & $\mathrm{I}$ & I & I & I & I & I & I & $\mathrm{I}$ & $100 \%$ \\
\hline 37 & Menyeru kepada kebaikan & $\mathrm{I}$ & I & $\mathrm{I}$ & $\mathrm{I}$ & 1 & I & I & $\mathrm{I}$ & I & $\mathrm{I}$ & $100 \%$ \\
\hline 38 & Mencegah keburukan & $\mathrm{I}$ & I & I & II & II & I & I & I & I & $\mathrm{I}$ & $90 \%$ \\
\hline & Membalas kejahatan dengan & & & & & & & & & & & $95 \%$ \\
\hline 39 & kebaikan & $\mathrm{I}$ & I & I & II & I & I & I & $\mathrm{I}$ & I & $\mathrm{I}$ & \\
\hline 40 & Bersikap toleransi & $\mathrm{I}$ & I & I & I & 1 & I & I & I & I & $\mathrm{I}$ & $100 \%$ \\
\hline 41 & Memaafkan kesalahan orang lain & $\mathrm{I}$ & I & I & $\mathrm{I}$ & 1 & I & I & $\mathrm{I}$ & I & $\mathrm{I}$ & $100 \%$ \\
\hline 42 & $\begin{array}{l}\text { Menepati janji kepada orang lain } \\
\text { Mendamaikan konflik yang terjadi di }\end{array}$ & I & I & I & I & I & I & I & I & I & I & $\begin{array}{l}100 \% \\
100 \%\end{array}$ \\
\hline 43 & lingkungan & $\mathrm{I}$ & I & I & I & $\mathrm{I}$ & I & I & $\mathrm{I}$ & I & $\mathrm{I}$ & \\
\hline 44 & Bersikap dermaan & $\mathrm{I}$ & I & I & I & I & I & I & I & I & I & $100 \%$ \\
\hline
\end{tabular}

Keterangan: Angka 1-10 menunjukkan responden

I menyatakan pendapat setuju dan II menyatakan pendapat tidak setuju

Berdasarkan data tersebut seluruh mahasiswa setuju dengan persentase $100 \%$ bahwa tokoh utama tolong menolong antar tetangga kerena saling membantu dengan tetangganya, keluarga Maria, yang berbeda agama, suku, dan negara. Tokoh utama menolong Maria membelikan titipan keperluan kuliahnya. Mahasiswa juga berpendapat bahwa tokoh utama juga menolong tetangganya Noura yang selalu disiksa dan dimaki oleh Ayah dan saudaranya sendiri. Tokoh utama saling tolong menolong dengan teman-teman satu flatnya, mulai dari menyiapkan makanan bersama, membersihkan rumah, sampai dengan menyiapkan air untuk mandi. Mereka melakukannya secara bergiliran sesuai jadwal dan terkadang juga sesuai dengan inisiatif karena mereka saling peduli dan tolong menolong.

Wulandari Nur Fajriyah, Yumna Rasyid, Nuruddin | Resepsi Mahasiswa Terhadap Nilai Moral Tokoh Utama 
Selanjutnya, berdasarkan data tersebut seluruh mahasiswa dengan persentase $100 \%$ menyatakan setuju bahwa tokoh utama mau menolong orang yang sedang kesusahan karena menolong Maria yang kesusahan ketika mau membeli disket dan menolong Noura yang mengalami kesusahan karena tidak ada satupun tetangga yang mau menolongnya. Tokoh utama juga mau menolong Aisyah, Alicia, dan teman-temannya yang sedang kesusahan dipojokkan makian orang-orang Mesir dalam metro.

Berdasarkan tanggapan mahasiswa setuju dengan persentase 95\% menyatakan bahwa tokoh utama memberikan kesempatan orang untuk berpendapat sama dengan pendapat mahasiswa terhadap tokoh utama mau mendengarkan saran serta masukan dari teman, istri, guru, serta orang-orang yang berada di sekitarnya. Misalnya, pada saat sebelum menghadiri undangan ulang tahun keluarga Maria dan memberikan kado, bersama teman-temannya tokoh utama mendengarkan bebagai pendapat sebelum memutuskan untuk datang atau tidak. Selain itu, tokoh utama juga memberikan kesempatan pada teman-temannya untuk berpendapat dan menjelaskan jadwal kegiatan serta aktifitasnya guna membuat jadwal membersihkan rumah, berbelanja, memasak, dan lain sebagainya sehingga tidak memberatkan teman-temannya. Mahasiswa juga menyatakan pendapat bahwa tokoh utama mau memberikan kesempatan istrinya untuk berpendapat dalam menghadapi masalah tuduhan yang tidak benar sampai dipenjara. Selain itu, tokoh utama memberikan kesempatan berpendapat kepada istrinya sebelum memutuskan untuk menikah dengannya ketika ta'aruf. Istrinya yakin akan pilihannya kepada Fahri dan siap hidup mulai dari nol bersama Fahri, pendapat tersebut menyakinkan hati Fahri untuk menjadikan Asiyah sebagi istrinya. Pendapat lain juga menyatakan bahwa tokoh utama memberikan kesempatan dan mendengarkan saran Ibu Maria agar Fahri istriahat total dan mengurangi aktifitasnya sampai benar-benar sembuh.

Selanjutnya, tanggapan mahasiswa terhadap tindakan tokoh utama menyeru kepada kebaikan karena tokoh utama mengajak semua orang yang berada di sekitarnya untuk berbuat kebaikan tanpa mengenal batas ruang dan waktu. Jadi, untuk melakukan perbuatan baik dan mengajak orang lain berbuat baik dilakukan kapanpun, di manapun, dan kepada siapapun. Misalnya, ketika mendamaikan perselisihan di metro, tokoh utama meyeru kepada kebaikan kepada kaum muslim untuk menaati perintah Allah dan Rasul dalam memuliakan tamu. Orang asing yang berada dalam metro merupakan tamu yang sudah mendapatkan izin dan membayar visa untuk datang dan berkunjung di tanah Mesir. Pendapat lain juga menyatakan bahwa tokoh utama taat beribadah shalat lima waktu dan taat pada perintah Allah, menunjukkan bahwa dengan melakukan shalat akan mencegah perbuatan buruk dan melahirkan perbuatan baik. Pendapat tersebut berdasarkan ayat Alquran yang menyatakan "shalat dapat mengajak berbuat hal-hal baik dan mencegah perbuat buruk". Hal tersebut terbukti dengan akhlak tokoh utama yang selalu berbuat kebaikan dan dapat mengamalkan isi Alquran dalam kehidupan sehari-hari. Tokoh utama berakhlak baik dan memberikan contoh atau teladan yang baik juga bagi orang-orang yang berada di sekitar tokoh utama sehingga dapat memotivasi untuk dapat melakukan hal-hal baik.

Berikutnya, tanggapan mahasiswa dengan persentase $90 \%$ terhadap tindakan tokoh utama dalam mencegah keburukan. Terdapat kaitannya dengan pendapat sebelumnya 
terhadap tindakan tokoh utama menyeru kepada kebaikan. Dalam mencegah kepada keburukan tokoh utama dinilai orang yang cinta damai. Misalnya, saat orang Mesir menghujat orang Asing, tokoh utama mencegah perbuatan buruk orang Mesir tersebut dengan mengajaknya bershalwat dan memberikan pengertian mengenai anjuran untuk memuliakan tamu, bahwa orang asing merupakan tamu yang sudah mendapatkan izin untuk mengunjungi Mesir. Tokoh utama juga mencegah keburukan Bahadur, Ayah Noura, dan sudara Noura yang terus menerus memaki dan memukul Noura dengan menyelamatkan Noura. Mahasiswa juga menyatakan bahwa tokoh utama dapat mencegah keburukan yang ada dalam dirinya, seperti melawan hawa nafsu dan sifat malas. Sifat tercela tersebut merupakan gangguan dari setan yang ingin memperdaya manusia, tokoh utama sadar perbuatan tersebut merupakan perbuatan yang merugikan.

Selanjutnya, tanggapan mahasiswa setuju dengan persentase $95 \%$ menyatakan bahwa tokoh utama membalas kejahatan dengan kebaikan karena tokoh utama yang penyabar dalam menghadapi ujian kejahatan orang lain menjadikan pribadi yang tidak pendendam terhadap orang yang telah berbuat kejahatan kepada dirinya. Mahasiswa menyatakan bahwa tokoh utama tidak dendam kepada Noura yang telah memfitnahnya sampai di penjara. Tokoh utama menerima ujian tersebut dengan kesabaran. Mahasiswa juga menyatakan bahwa, tokoh utama justru mau memaafkan dengan ikhlas serta mendoakan kebaikan untuk Noura yang telah memfitnahnya. Hal tersebut menunjukkan bahwa tokoh utama menunjukkan sifat sabar, ikhlas menerima ujian yang diberikan Noura terhadapnya dan tidak membalas kejahatan Noura dengan kejahatan. Tanggapan mahasiswa juga menyatakan bahwa tokoh utama tidak membalas kejahatan orang Mesir yang telah memaki wanita muslim dan orang Asing.

Seluruh mahasiswa menyatakan setuju dengan persentase $100 \%$ terhadap tindakan toleransi tokoh utama. Berdasarkan pendapat mahasiswa, tokoh utama bersikap toleransi terhadap orang yang berbeda agama dan berbeda negara, yaitu: toleransi kepada keluarga Maria dan Alicia serta teman-temannya. Keluarga Maria orang Mesir yang menganut agama Katolik merupakan tetangga flat tokoh utama dan teman-temannya. Di saat tokoh utama sakit, keluarga Maria menjenguk dan membantu ketika tokoh utama kesusahan. Begitupula dengan tokoh utama juga sering membantu keluarga Maria untuk membelikan titipan kebutuhan Maria. Sikap saling membantu dan menghormati tersebut memberikan hubungan baik antara tokoh utama dengan keluarga Maria, mereka saling hidup damai dan beriringan walaupun beda keyakinan dan berbeda negara. Begitupula toleransi yang dilakukan oleh tokoh utama kepada Alicia dan teman-temannya. Alicia dan teman-temannya merupakan turis asing Amerika yang sedang berkunjung di Mesir, salah satu teman Alicia yang sudah paruh baya kecapaian dan kepanasan dan membutuhkan tempat duduk dalam metro. Melihat hal tersebut, Aisyah, mahasiswa yang berasal dari Turki, yang sedang duduk segera memberikan tempat duduknya kepada teman Alicia. Tindakan Aisyah tersebut mendapatkan kecaman dan makian dari orang Mesir karena telah memberikan kursi duduknya untuk orang asing tersebut. Orang asing tersebut juga mendapatkan makian yang sangat tajam dari orang Mesir. Hal tersebut membuat hati tokoh utama untuk membantu menengahi permasalahan tersebut dengan meredam amarah orang Mesir dengan mengajak bershalawat dan 
memberikan pencerahan bahwa orang asing tersebut adalah tamu yang harus diperlakukan baik dan dalam ajaran Islam seharusnya kita dapat memuliakan tamu bukan dengan memberikan makian.

Berdasarkan data tersebut seluruh mahasiswa setuju dengan persentase $100 \%$ bahwa tokoh utama mudah memaafkan kesalahan orang lain karena tokoh utama orang yang ikhlas memaafkan kesalahan Noura yang telah memfitnahnya. Selain tokoh utama ikhlas, pendapat mahasiswa menyatakan bahwa tokoh utama orang yang sabar dan tulus sehingga dapat dengan mudah memaafkan kesalahan Noura dan orang-orang yang telah menyakit tokoh utama. Tokoh utama juga mendoakan kebaikan untuk Noura dan orang-orang yang telah melakukan kesalahan kepada tokoh utama. Tokoh utama juga sabar menjalani proses penahanan hingga putusan pengadilan.

Sikap tokoh utama dalam menepati janji mendapatkan tanggapan setuju dari seluruh mahasiswa dengan persentase $100 \%$. Mahasiswa berpendapat bahwa tokoh utama menepati janji kepada Alicia untuk datang tepat waktu. Perjanjian tersebut terjadi setelah tokoh utama menolong Alicia dan teman-temannya dalam metro. Alicia yang merupakan salah satu wartawan majalah Amerika terkesima dan tertarik dengan ajaran Alquran yang disampaikan oleh tokoh utama kemudian Alicia berinisiatif untuk mewawancarai tokoh utama mengenai posisi wanita dalam agama Islam. Tokoh utama menerima tawaran untuk diwawancarai oleh Alicia. Alicia datang telat sedangkan tokoh utama datang tepat waktu dalam perjanjian tersebut. Peristiwa tersebut menunjukkan bahwa tokoh utama dapat menepati janji yang telah dibuat dengan Alicia dengan datang tepat waktu. Mahasiswa berpendapat bahwa tokoh utama bersikap disiplin dan berkomitmen tinggi dengan akifitasnya sehingga tokoh utama selalu hadir dalam perkuliahan dan jadwal mengaji. Tak peduli cuaca yang sangat panas di Mesir, tokoh utama tetap berangkat ke tempat mengaji. Mahasiswa juga menyatakan bahwa tokoh utama dapat mengatur aktifitas dan jadwalnya dalam beberapa hari kedepan dengan mengatur jadwal aktifitasnya, tokoh utama dapat mengatur dan menyesuaikan jadwalnya sebelum janji yang baru dibuat.

Selanjutnya, berdasarkan data tanggapan mahasiswa setuju dengan persentase $100 \%$ menyatakan bahwa tokoh utama dapat mendamaikan konflik. Mahasiswa berpendapat ada dua konflik yang dapat didamaikan oleh tokoh utama. Pendapat ini sama dengan pendapat mahasiswa terhadap tokoh utama bersikap tolong menolong antar tetangga dan tolong menolong kepada orang yang berada di sekitarnya. Tokoh utama mampu mendamaikan konflik yang terjadi pada tetangganya, Noura dengan menolong Noura. Konflik yang selalu terjadi setiap hari adalah mendengar Noura dicaci maki dan dipukul oleh Ayah dan saudarasaudarnya. Dengan menolong Noura berarti tokoh utama dapat mendamaikan konflik, kemudian untuk sementara Noura tinggal di asrama putri Indonesia bersama Nurul, teman tokoh utama, untuk dapat menemukan solusi dari permasalahan yang dihadapinya. Konflik kedua yang dapat didamaikan oleh tokoh utama adalah konflik yang terjadi antara orang Mesir dengan Aisyah, Alicia, dan teman-temannya yang merupakan orang asing yang sedang berkunjung di Mesir. Konflik tersebut bermula ketika Aisyah memberikan kursi kepada teman Alicia yang sudah separuh baya dan terlihat pucat karena kelelahan panasnya Mesir. Peristiwa tersebut mendapatkan kecaman keras dari orang Mesir. Aisyah, Alicia, dan

Wulandari Nur Fajriyah, Yumna Rasyid, Nuruddin | Resepsi Mahasiswa Terhadap Nilai Moral Tokoh Utama 
teman-temannya medapatkan makian dan hujatan dari orang Mesir yang memojokkan mereka. Konflik tersebut membuat tokoh utama berinisiatif untuk mendamaikannya, dimulaidari meredam amarah orang-orang Mesir dengan mengajaknya bershalawat kemudian memberikan pengertian bahwa sebagai muslim, seharusnya dapat memuliakan tamu, orang asing. Perintah memuliakan tamu sudah jelas dalam Alquran dan hadis, "orang yang beriman pada Allah dan hari akhir makan hendaklah memuliakan tamu”. Alicia dan teman-temannya merupakan tamu di negara Mesir karena sudah mendapatkan izin dan membayar visa utuk mngunjungi Mesir, seharusnya sebagai muslim menunjukkan kepada tamu yang berbeda keyakinan dan negara bahwa islam cinta perdamaian dan memuliakan tamu.

Sikap tokoh utama dermawan mendapatkan tanggapan setuju dari seluruh mahasiswa dengan persentase $100 \%$. Mahasiswa berpendapat bahwa tokoh utama orang yang tidak perhitungan ketika mendapatkan kabar bahagia proposal tesisnya diterima, tokoh utama membagikan kebahagiannya dengan mengajak teman-temannya makan bersama. Selain berbagi dengan teman-temannya, tokoh utama juga berbagi dengan tetangganya dengan mengirimkan makanan kepada keluarga Maria dan memberikan kado ulang tahun kepada Ibu Maria dan adik Maria. Mahasiswa juga berpendapat bahwa tokoh utama orang yang dermawan karena memberikan sebagian hartanya kepada yang berhak. Sifat tidak boros dan dapat mengatur keuangannya, tokoh utama dapat memberikan sebagian uangnya untuk anak yatim piatu dan orang yang berhak menerimanya. Selain dapat memberikan sebagian uangnya untuk orang yang berhak, tokoh utama juga dinilai dermawan dalam ilmu. Tokoh utama dinilai tidak pelit jika ditanya mengenai suatu ilmu, justru tokoh utama senang membagikan ilmu yang telah diperolehnya kepada orang-orang disekitarya. Misalnya, ketika diwawancarai Alicia mengenai wanita dalam pandangan Islam, dengan senang hati tokoh utama bersedia diwawancarai.

\section{Simpulan}

Berdasarkan hasil analisis dan interpertasi data dari respons yang telah diberikan mahasiswa, dapat diketahui bahwa sebagian besar mahasiswa memberikan respons setuju dengan persentase 9,3\%. yang menunjukkan bahwa nilai moral agama tokoh utama baik. Mahasiswa menyatakan bahwa tokoh utama memiliki keyakinan kuat kepada Allah karena rajin beribadah, taat, sabar, dan tabah dalam melaksanakan perintah Allah dan menjauhi larangan Allah, bersikap rendah hati kepada Allah, berserah diri atas segala takdir Allah, bersyukur atas segala nikmat yang telah diberikan Allah, teguh pendirian dalam melaksanakan ibadah, taat, dan berprilaku terpuji, merasa semua yang dimiliki hanyalah titipan Allah, bedoa hanya kepada Allah, selalu mengingat Allah, dan bersikap malu karena melanggar perintah Allah.

Berdasarkan hasil analisis dan interpretasi data dari tanggapan yang diberikan mahasiswa, dapat diketahui bahwa sebagian besar siswa memberikan respon setuju dengan persentase $9,0 \%$ yang menunjukkan nilai moral kepribadian tokoh utama baik. Tanggapan mahasiswa terhadap nilai moral kepribadian tokoh utama menyatakan baik karena tokoh utama dapat menjaga kebersihan, kesehatan, dan kesucian diri, bersikap mandiri, dapat

Wulandari Nur Fajriyah, Yumna Rasyid, Nuruddin | Resepsi Mahasiswa Terhadap Nilai Moral Tokoh Utama 
menghormati orang-orang yang berada di sekitarnya, dapat berkomuikasi dengan baik, mempertahankan sikap yang diyakini, bersedia mengambil risiko, dapat menyelesaikan tugas terjemahan dan kuliah dengan sebaik mungkin, bersikap tanpa pamrih, bertanggungjawab sebagai mahasiswa, suami, dan penerjemah, konsisten dalam bersikap terpuji, tidak menyakiti dan tidak memaki orang yang berada di sekitarnya, tidak merasa takut kepada orang lain, hanya takut kepada Allah, bersikap saling berbagi dengan teman-temannya, mau mendengarkan semua pihak secara terbuka sebelum memberikan penilaian, berani berpihak pada yang lebih lemah, menyadari tanggung jawab realistik kewajibannya sebagai mahasiswa dan suami, dan tidak mudah bersedih menghdapi ujian hidup seperti di penjara dalam novel Ayat-ayat Cinta 1 karya Habiburrahman El Shirazy.

Berdasarkan hasil analisis dan interpretasi data dari tanggapan yang diberikan mahasiswa, dapat diketahui bahwa sebagian besar siswa memberikan respon setuju dengan persentase 9,6\% yang menunjukkan nilai moral sosial tokoh utama baik. Tanggapan mahasiswa terhadap nilai moral sosial tokoh utama menyatakan baik dan dapat diteladani oleh pembaca. Respon mahasiswa setuju bahwa tokoh utama saling tolong menolong antar tetangga, menolong Noura dan keluarga Maria. Tokoh utama membantu orang yang sedang kesusahan, membantu Noura, Maria, Aisyah, Alicia dan teman-temannya. Tokoh utama dapat mengambil keputusan berdasarkan kepentingan bersama teman dan istrinya, memberikan kesempatan kepada orang lain untuk berpendapat sebelum melakukan tindakan, menyeru kepada kebaikan dan menjadi contoh untuk berbuat kebaikan, mencengah keburukan yang terjadi di metro dan di tetangga flatnya, membalas kejahatan Noura dengan kebaikan memaafkannya dan mendoakan kebaikan untuk Noura, bersikap toleransi terhadap orang yang berbeda agama dan berbeda negara, mau memaafkan kesalahan Noura yang telah memfitnahnya, mampu menepati janji untuk datang tepat waktu saat wawancara Alicia, dapat mendamaikan konflik yang terjadi dengan Noura dan Alicia, dan bersikap dermawan dengan saling berbagi serta memberikan hartanya untuk orang yang berhak.

\section{Daftar Pustaka}

Bertens, K. (2011). Etika. Jakarta: Gramedia.

Nasharuddin. (2015). Akhlak:Ciri Manusia Paripurna. Jakarta: Rajawali Press.

Niken S. M. (2015). “Analisis Resepsi Sastra Cerita Sambung Ngonceki Impen karya Sri

Sugiyanto". Jurrnal Program Studi Pendidikan Bahasa dan Sastra Jawa Universitas Muhammadiyah Purworejo.

Nur K. H, dkk. (2012). "Nilai-Nilai Moral dalam Novel Negeri Lima Menara karya A.Fuadi”. Jurnal Online Universitas Negeri Malang Vol. 1 No. 1.

Santosa, P. (2017). "Resepsi Sastra Kisah Gandari dalam Puisi Indonesia Modern”. Jurnal Aksara, Vol. 29 No.1, Juni.

Segers, R. T. (2000). Evaluasi Teks Sastra (Terjemahan Suminto A. Sayuti). Yogyakarta: Adicita.

Soeparwoto. (2004). Psikologi Perkembangan. Semarang: Unnes Press.

Suseno, F. M.(2005). Etika Dasar: Masalah-masalah Pokok Filsafat Moral. Yogyakarta: Kanisius. 
Deiksis: Jurnal Pendidikan Bahasa dan Sastra Indonesia, 6 (2) Juli 2019 DOI:10.33603/dj.v6i2.1330

Wellek, R dan Austin, W.(2014). Teori Kesusastraan Terjemahan Melani Budianata. Jakarta: Gramedia Pustaka Utama.

Zuriah, N.(2008). Pendidikan Moral \& Budi Pekerti dalam Perspektif Perubahan. Jakarta: Bumi Aksara. 